\title{
Supramolecular Chemistry of Selective Anion Recognition for Anions of Environmental Relevance
}

\author{
Final Report from Prof. Sessler for: \\ Environmental Management Science Program, Project \#74019 \\ Results at Oak Ridge National Laboratory
}

Bruce A. Moyer (Co-PI), Debra A. Bostick, Christopher J. Fowler, Hyun-Ah Kang, Alexandre Ruas, Lætitia H. Delmau, and Tamara J. Haverlock, Chemical Sciences Division, Oak Ridge National Laboratory, P.O. Box 2008, Oak Ridge, TN 37830-6119

José M. Llinares, Md. Alamgir Hossain, S. O. Kang, and Kristin Bowman-James (Lead PI) Department of Chemistry, University of Kansas, 1251 Wescoe Hall Drive, Lawrence, Kansas 66045-7582

James A. Shriver, Manuel Marquez, Evgeny Katayev, Natalie Barkey, and Jonathan L. Sessler (Co-PI)

Department of Chemistry and Biochemistry, University of Texas, 1 University Station A5300, Austin, Texas 78712-0165

September 21, 2006

This research was sponsored by the Environmental Management Science Program of the Office of Science, U. S. Department of Energy, under a) contract no. DE-AC05-00OR22725 with Oak Ridge National Laboratory, managed and operated by UT-Battelle, LLC; Grant Nos. DE-FG96ER62307 and DE-FG02-04ER63745 to the University of Kansas; and c) Grant DE-FG0204ER63741 to the University of Texas, Austin. Any opinions, findings, conclusions, or recommendations expressed herein are those of the authors and do not necessarily reflect the views of DOE. Any opinions, findings, conclusions, or recommendations expressed herein are those of the authors and do not necessarily reflect the views of DOE. 


\title{
FINAL REPORT
}

\author{
U.S. Department of Energy
}

\section{Supramolecular Chemistry of Selective Anion Recognition for Anions of Environmental Relevance Results From Research Conducted at The University of Texas at Austin}

Lead Principal Investigator: Prof. Kristin Bowman-James, Department of Chemistry, University of Kansas, 1251 Wescoe Hall Drive, Lawrence, Kansas 66045-7582. Phone: 785-864-3669. Fax: 785-864-5396. E-mail: kbjames@ku.edu

Co-Principal Investigator: Bruce A. Moyer, Oak Ridge National Laboratory, Bldg. 4500S, MS 6119, P.O. Box 2008, Oak Ridge, TN 37831-6119. Phone: 865-574-6718. Fax: 865-574-4939. Email: moyerba@ornl.gov

Co-Principal Investigator: Lætitia H. Delmau, Oak Ridge National Laboratory, Bldg. 4500S, MS 6119, P.O. Box 2008, Oak Ridge, TN 37831-6119. Phone: 865-576-2093. Fax: 865-574-4939. Email: delmaulh@ornl.gov

Co-Principal Investigator: Prof. Jonathan L. Sessler, Department of Chemistry and Biochemistry, University of Texas, 1 University Station - A5300, Austin, Texas 78712-0165. Phone: 512-4715009. Fax: 512-471-7550. E-mail: sessler@mail.utexas.edu

Statistics since start of renewal Oct. 1, 2004: (University of Texas only)

Number of undergraduate students: 1

Number of graduate students: 4

Number of postdocs: 2

EMSP Project:

Contract \#:

Project Duration (Renewal): Univ. of Texas Accountant:
\#74019

DE-AC05-00OR22725 (ORNL, FWP No. ERKP600)

DE-FG-96ER62307 and DE-FG02-04ER63745 (KU)

DE-FG02-04ER63741 (UT, Austin)

Oct. 1, 2004 - Sept. 30, 2007

Susan Jan Dunston, Office of Accounting - Grants and Contracts, The University of Texas at Austin, 1 University Station, Austin, TX 78712. Phone: (512) 232 6533. E-mail: jdunston@austin.utexas.edu 


\section{Summary}

The major thrust of this project, led by the University of Kansas (Prof. Kristin BowmanJames), entails an exploration of the basic determinants of anion recognition and their application to the design, synthesis, and testing of novel sulfate extractants. A key scientific inspiration for the work comes from the need, codified in simple-to-appreciate terms by the Oak Ridge National Laboratory component of the team (viz. Dr. Bruce Moyer), for chemical entities that can help in the extractive removal of species that have low solubilities in borosilicate glass. Among such species, sulfate anion, has been identified as particularly insidious. Its presence interferes with the vitrification process, thus rendering the remediation of tank waste from, e.g., the Hanford site far more difficult and expensive. The availability of effective extractants, that would allow for the separation of separating sulfate from the major competing anions in the waste, especially nitrate, could allow for pre-vitrification removal of sulfate via liquid-liquid extraction. The efforts at The University of Texas, the subject of this report, have thus concentrated on the development of new sulfate receptors. These systems are designed to increase our basic understanding of anion recognition events and set the stage for the development of viable sulfate anion extractants. In conjunction with the Oak Ridge National Laboratory (ORNL) members of the research team, several of these new receptors were studied as putative extractants, with two of the systems being shown to act as promising synergists for anion exchange.

\section{Research Objectives}

The goal of this project was to develop highly selective extractants that would be capable of removing sulfate anion from nuclear wastes prior to vitrification. Sulfate separation offers potential value in the cleanup of the Hanford tanks in that sulfate interferes with making glass. One option for dealing with this potentially costly problem is to remove the sulfate from the waste using a combination of anion binding and extraction. This approach is attractive because it is potentially selective, cheap, and amenable to scale-up. However, many fundamental issues needed to be addressed before such an approach became practical. This project was thus instigated with a view to addressing many of these underlying issues. Towards this end, it was felt necessary to understand the determinants of anion binding in general and those of sulfate recognition in particular. The hope was then to parlay this understanding into the design of useful extractants that could be used to achieve efficient separations. The work at the Univ. of Texas has mostly focused on the recognition and design aspects, as has that of the lead project P.I., Prof. Kristin Bowman-James at the Univ. of Kansas. By contrast, that of the third co-P.I., Dr. Bruce Moyer at ORNL, has focused on the development of substrate-specific liquid-liquid extraction protocols. The results in this report will thus focus on the synthetic and anion recognition aspects of the project as advanced by work carried out at the Univ. of Texas. It summarizes work performed in FYs 2004-2006. 


\section{Research Results}

Work at carried out at ORNL since the inception of the project has served to demonstrate that the calix[4]pyrroles (e.g., 1-3) from the co-P.I.’s laboratory at the Univ. of Texas strongly enhance the extraction of sulfate by tricaprylmethylammonium nitrate or chloride in the presence of excess nitrate and chloride. Similar results were found in the case of the tetraamide macrocycles synthesized in the Bowman-James laboraroty (Univ. of Kansas). Effort at the Univ. of Texas thus focused on generating new pyrrole-amide macrocycles that might combine the most favorable aspects of the calixpyrroles and the tetraamides. This culminated in the synthesis of compounds 4-7, which provided a "matched set" from whence insights into anion recognition could be inferred. As can be inferred from the data summarized in Table 1, small adjustments in the structure allow for a fine-tuning of the anion binding properties in favor of sulfate recognition, or in the case of other modifications, selectivities that favor different anions.
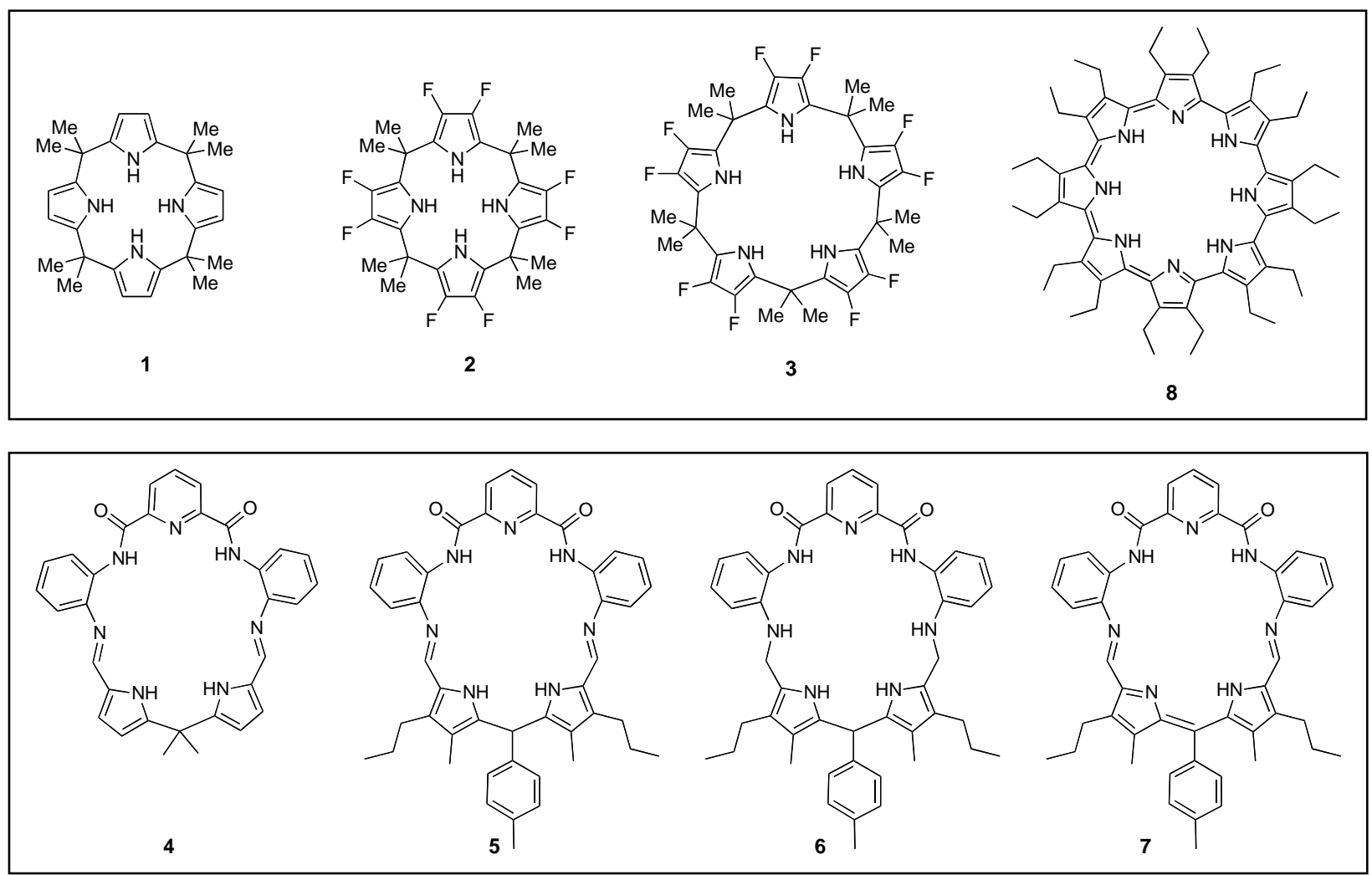

On the basis of this work, it is concluded that a combination of subunit rigidity combined with a high degree of overall macrocycle flexibility favors sulfate and that systems that either too "floppy" or too constrained will favor other tetrahedral anions or halide anions, respectively.

An interesting off-shoot of this work was the discovery that ligands related to 4-7 will open up and reform to produce other isomeric species when exposed to certain templating conditions. While not germane to the problem of sulfate recognition per se (other than the fact that the resulting products appear to have particularly high affinities for tetrahedral anions), this work is a "big deal" in terms of demonstrating a new approach to combinatorial chemistry. 
Table 1. $K_{\mathrm{a}}$ values, $\mathrm{M}^{-1}$; $\mathrm{CH}_{3} \mathrm{CN}, 296 \mathrm{~K}$

\begin{tabular}{|c|c|c|c|c|}
\hline Anion & 4 & 5 & 6 & 7 \\
\hline $\mathrm{Br}^{-}$ & N.B. ${ }^{a}$ & N.B. ${ }^{a}$ & N.B. ${ }^{a}$ & $2760 \pm 380$ \\
\hline $\mathrm{NO}_{3}^{-}$ & N.B. ${ }^{a}$ & N.B. ${ }^{a}$ & N.B. ${ }^{a}$ & N.B. ${ }^{a}$ \\
\hline $\mathrm{Cl}^{-}$ & $2000 \pm 23$ & N.B. ${ }^{a}$ & $116000 \pm 11000$ & N.B. ${ }^{a}$ \\
\hline $\mathrm{CH}_{3} \mathrm{COO}^{-}$ & $38,000 \pm 3000$ & $12600 \pm 450$ & $67000 \pm 9900$ & N.B. ${ }^{a}$ \\
\hline $\mathrm{HSO}_{4}^{-}$ & $64,000 \pm 2600$ & $108000 \pm 17000$ & $4700 \pm 960$ & N.B. ${ }^{a}$ \\
\hline $\mathrm{H}_{2} \mathrm{PO}_{4}^{-}$ & 342,$000 ; 26,000^{b}$ & $29000 \pm 1900$ & $15500 \pm 1750$ & N.B. ${ }^{a}$ \\
\hline
\end{tabular}

In addition to the work on new classes of pyrrole amide receptors, efforts were devoted to studying further the anion binding properties of calix[4]pyrroles. Here, a very exciting discovery was made, namely that these species can serve as ion pair receptors, binding not only an anion but a counter cation as well. This finding, which has important implications in terms of extraction-type applications, is animating the study of other electronically modified calix[n]pyrroles ( $n=4$ and 5). Of particular interest are systems that have been subject to electronic modification (e.g., 2 and 3), since, as in the case of the simple calix[4]pyrroles (e.g. 1), data from the ORNL team provides support for the notion that these species are highly effective as sulfate anion extractants. This work, in turn, has inspired the construction of other pyrrolebased anion receptors. Towards this end efforts have been devoted to combining the pyrrole anion binding functionality developed in the Sessler group with the cavitands of Prof. Bruce Gibb, who spent the 2005-06 academic year at The Univ. of Texas as the result of being displaced from his home institution (Univ. of New Orleans) by Hurricane Katrina. This work is still at an early stage.

More advanced is work with ORNL that has served to demonstrate that organic solubilized cyclo[n]pyrroles (e.g., 8; $\mathrm{n}=8$ ) show promise as sulfate anion extractants. Unfortunately, while near quantitative extraction of radiolabeled sulfate anion was seen, the kinetics of the binding and release process proved slow. This leads to the suggestion that future work should focus on the hitherto unexplored problem of binding kinetics.

\section{Conclusion and Summary Comments}

Taken in concert, the results from this study serve to underscore the notion that rational design may be used to prepare receptors that are selective for sulfate anion. The best systems show considerable promise as extractants, although further fine-tuning in terms of organic solubility and kinetics of binding and release will be needed before they are ready for use in a viable extraction-based sulfate removal process. However, it now appears that such a process could be made workable in short order provided resources were devoted to its implementation. 


\section{Information Access}

All relevant experimental data are included in the publications arising from this project. See also the home page of the Sessler group: http://research.cm.utexas.edu/jsessler/.

Publications and Presentations: October 1, 2004 - September 15, 2006

\section{Refereed Publications Acknowledging this Grant}

1. Sessler, J. L.; Katayev, E.; Pantos, G. D.; Ustynyuk, Y. A. "Synthesis and study of a new diamidodipyrromethane macrocycle. An anion receptor with a high sulfate-to-nitrate binding selectivity,” Chem. Commun. 2004, 1276-1277. Featured in C \& E News: "Macrocycle for Nuclear Waste,” Chemical Engineering News, June 7, 2004, p. 8.

2. Sessler, J. L.; Cho, W. S.; Gross, D. E.; Shriver, J. A.; Lynch, V. M.; Marquez, M.; “Anion Binding Studies of Fluorinated Expanded Calixpyrroles,” J. Org. Chem. 2005, 70, 59825986.

3. Sessler, J. L.; Katayev, E.; Pantos, D. G.; Scherbakov, P.’ Reshetova, M. D.; Khrustalev, V. N.; Lynch, V. M.; Ustynyuk, Y. A. "Fine Tuning the Anion Binding Properties of 2,6Diamidopyridine Dipyrromethane Hybrid Macrocycles,” J. Am. Chem. Soc 2005, 127, 11442-11446.

4. Custelcean, R.; Moyer, B. A.; Sessler, J. L.; Cho, W.-S.; Gross, D.; Bates, G. W.; Brooks, S. J.; Light, M. E.; Gale, P. A. Angew. Chem. Int. Ed. 2005, 44, 2537-2542; Angew. Chem. 2005, 117, 2513-2518. Featured on the cover.

5. Sessler, J. L.; Katayev, E. A.; Pantos, G. D.; Reshetova, M. D.; Khrustalev, V. N.; Lynch, V. M.; Ustynyuk, Y. A. "Anion Induced Synthesis and Combinatorial Selection of Polypyrrolic Macrocycles,” Angew. Chem. 2005, 117, 7552-7556; Angew. Chem. Int. Ed. 2005, 44, 73867390 .

6. Moyer, B.A.; Delmau, L. H.; Fowler, C. J.; Ruas, A.; Bostick, D. A.; Sessler, J. L.; Katayev, E.; Pantos, G. D.; Llinares, J. M.; Hossain, M. A.; Kang, S. O.; Bowman-James, K. "Supramolecular Chemistry of Environmentally Relevant Anions," Adv. Inorg. Chem, in press.

7. Sessler, J. L.; Roznyatovskiy, V.; Pantos, G. D.; Borisova, N. E.; Reshetova, M. D.; Lynch, V. M.; Khrustalev, V. N.; Ustynyuk, Y. A. "Synthesis and Anion Binding Properties of 2,5diamido-thiophene Polypyrrole Schiff-Base Macrocycles,” Org. Lett. 2005, 7, 5277-5280.

8. Katayev E. A., Pantos, G. D., Lynch, V. M., Sessler, J. L., Reshetova, M. D., Ustynyuk Y. A. "New polydentate inacrocyclic ligands of hybrid amine-imine and amide-imine types as artificial anion receptors. Synthesis and study of anion binding,” Russ. Chem. Bull. 2005, 54, 165-172. 


\section{Other Publications and Presentations}

1. Bowman-James, K.: Moyer, B. A.; Sessler, J. L. "Supramolecular Chemistry of Environmentally Relevant Anions,” American Chemical Society National Meeting, New York, NY, Sept. 7-11, 2003.

2. Moyer, B. A.; Bonnesen, P. V.; Custelcean, R.; Delmau, L. H.; Haverlock, T. J.; Bostick, D. A.; Gorbunova, M.; Kang, H-A; Fowler, C. J.; Levitskaia, T. G.; Kavallieratos, K.; Ruas, A.; Hay, B. P.; Sessler, J. L.; Cho, W.-S.; Shriver, J. A.; Bowman-James, K.; Llinares, J. M.: Hossain, M. A. "Using Coordination Chemistry to Selectively Separate Anions, From the Template Effect to Spontaneous Intermolecular Organization. A Celebration of Daryle Busch's first 50 years of Leadership, Teaching, Research and Service," $228^{\text {th }}$ ACS National Meeting, Philadelphia, PA, Aug. 22-16, 2004.

3. Moyer, B. A.; Kang, H.-A.; Fowler, C. J.; Levitskaia, T. G.; Delmau, L. H.; Ruas, A.; Bostick, D. A.; Haverlock, T. J.; Sessler, J. L.; Shriver, J. A.; Llinares, J. M.; Hossain, Md. A.; Bowman-James, K. "Synergized Liquid-Liquid Anion Exchange: Use of Anion Receptors to Enhance the Extraction of Sulfate from a Nitrate Matrix by a Quaternary Ammonium Extractant.” Chemistry \& Biochemistry Organic Division Seminar, Univ. of Texas, Austin, Aug. 5, 2004.

4. Sessler, J. L.; Cho, W.-S.; Gross, D. E.; Shriver, J. A.; Moyer, B. A.; Kang, H.-A.; Fowler, C. J.; Delmau, L. H.; Ruas, A.; Bostick, D. A.; Na, H.-K.; Lee, J.-S.; Lee, C.-H.; Marquez, M. "Calixpyrrole Families: Synthesis, Characterization, and Anion Binding/Extraction Studies," $13^{\text {th }}$ International Symposium on Supramolecular Chemistry, Notre Dame, Indiana, July 2530, 2004.

5. Moyer, B. A.; Fowler, C. J.; Delmau, L. H.; Ruas, A.; Bostick, D. A.; Sessler, J. L.; Shriver, J. A.; Llinares, J. M.; Hossain, Md. A.; Bowman-James, K. "Synergized Liquid-Liquid Anion Exchange: Use of Anion Receptors to Enhance the Extraction of Sulfate from a Nitrate Matrix by a Quaternary Ammonium Extractant,” 227th American Chemical Society National Meeting, Anaheim, CA, March 28-April 1, 2004.

6. Bowman-James, K.; Wilson, G. S.; Moyer, B. A. Supramolecular Chemistry of Selective Recognition for Anions of Environmental Relevance. Environmental Management Science Program Annual Report, Project \#74019; Oak Ridge National Laboratory: Oak Ridge, Tennessee, June 10, 2004; available on the World Wide Web site of the USDOE Environmental Management Science Program, URL http://emsp.em.doe.gov/portfolio/ProductDetails.asp?ProjectID=520 .

7. Sessler, J. L.; Cho, W.-S.; Gross, D. E.;_Shriver, J. A.; Moyer, B. A.; Custelcean, R.; Fowler, C. J.; Delmau, L. H.; Na, H.-K.; Lee, J.-S.; Lee, C.-H.; Marquez, M. "Calixpyrroles and Related Anion Receptors," $4^{\text {th }}$ International Symposium on Supramolecular Science and Technology, Prague, Czech Republic, September, 14, 2004. This was a plenary lecture.

8. Sessler, J. L.; Cho, W.-S.; Gross, D. E.; Shriver, J. A.; Moyer, B. A.; Custelcean, R.; Na, H.K.; Katayev, E. A.; Pantos, G. D.; Gale, P. A.; Lee, C.-H.; Marquez, M. “Calixpyrroles and 
Related Oligopyrrole Receptors,” Calix 2005, Prague, Czech Republic, August, 19, 2005. This was a Chem. Commun. $40^{\text {th }}$ Anniversary Award lecture.

9. "Calixpyrroles and Related Macrocycles," Hebrew University, Jerusalem, Israel, September, 2005.

10. “Calixpyrroles and Related Macrocycles,” Korean Chemical Society National Meeting, Seoul, South Korea, April, 2006. This was an invited keynote lecture.

11. "Calixpyrroles and Related Macrocycles," The University of Oviedo, Oviedo, Spain, June, 2006. 